\title{
Title: How Experiences of Climate Extremes Motivate Adaptation Among Water Managers
}

\author{
Published in Climatic Change Vol. 161: 499-516. April, 2020 \\ DOI: https://doi.org/10.1007/s10584-020-02712-7
}

NOTE: This document is provided for open access and is a version of the article pre-proof stage.

\author{
Authors: \\ Rebecca Page \\ Environmental Studies Program and Western Water Assessment \\ University of Colorado Boulder \\ Boulder, CO 80309 \\ Lisa Dilling* \\ Environmental Studies Program, Western Water Assessment, Center for Science and Technology \\ Policy Research, Cooperative Institute for Research in Environmental Sciences \\ UCB 397 \\ University of Colorado Boulder \\ Boulder, CO 80309 \\ *Corresponding Author: ldilling@colorado.edu
}

\begin{abstract}
As water systems are likely to experience mounting challenges managing for climate variability and extremes as well as a changing climate, there is increasing interest in what motivates systems to implement adaptive measures. While extreme events have been hypothesized to stimulate organization change and act as "windows of opportunity" and "pacemakers" driving toward adaptation, they do not always seem to do so. We therefore sought to understand the responses and motivations for organizational behavior in the wake of two significant droughts across 5 smaller water systems in Western Colorado, U.S.A. We conducted interviews and focus groups across these systems to understand whether and why significant droughts in 2002 and 2012 prompted adaptive change. Results indicate that systems did not uniformly decide to change their policies in the wake of drought, and even well-prepared systems were driven to change policies by other pressures, such as peer-system pressure and political pressure from residents. We find that organizational worldviews were important
\end{abstract}


mediators of how the experience of drought manifest, or not, in organizational changes. These findings have implications for assumptions about what might drive organizational learning and change among water managers for climate adaptation in the future.

Keywords: drought water climate adaptation organization policy

\section{Introduction}

Water resources in the Western United States are tightly managed, and communities across this region are facing increasing drought risks, especially as demand increases and the timing and volume of snowpack runoff shifts with climate change (Lukas et al., 2014). There is a need to understand what might drive increases in adaptation or adaptive capacity, especially among smaller water systems. Extreme climate events such as drought are often theorized as "windows of opportunity" for addressing climate risks and reducing societal vulnerability (Birkland 2006), and are thought to sometimes act as "pacemakers" driving adaptation to climate change (Travis 2014). Colorado's Western Slope region experienced two major drought events in the past twenty years (2002 and 2012) that some have said changed the mindset and behavior of water managers throughout the region. The 2002 drought in particular has been described as an event that "broke the usual pattern of responding to crisis and then returning to "business as usual' until the next disaster strikes" (Klein \& Kenney, 2006). However, the extent to which extreme climatic events act as windows of opportunity and result in increased adaptive capacity is contested, and results are mixed (Birkland, 2006, Christoplos, 2006). Studying actions taken during and in the aftermath of major drought events can help to deepen our understanding of how these extreme events might drive policy changes and learning within the water management sector (Busenberg 2001). 
In the water management context, some scholars have observed that, due to the conservative nature of water managers and water management institutions, most significant changes within water management result from some type of crisis (Huitema \& Meijerink, 2010; Jacobs \& Pulwarty, 2003), including drought events. Moreover, Birkmann et al. (2010) suggest that in light of climate change, it is especially important to study how learning takes place in organizations post-disasters, and understand how such events prompt more lasting learning and change. Water managers base much of their decision-making on historic hydrologic records, embedded in which are memories of how certain years "went" in terms of operational decisions. While some studies have explicitly looked at the ways in which water managers construct narratives about key operational lessons from past extreme events (e.g. Pulwarty \& Melis, 2001), many studies examining adaptive capacity within the water management sector have focused either on exogenous factors (e.g. institutional, economic, techno-scientific) that shape adaptive capacity (Berkhout, 2012; Granderson, 2014), or on industry-wide behavioral norms that inform how water managers' manage tradeoffs during drought events (e.g.prioritizing system reliability (Hashimoto et al., 1982; Lach et al., 2005), financial considerations, and water quality (Lach et al., 2005; Rayner et al., 2005); focusing on public support (Dilling et al., 2018; Hornberger et al., 2015; Lach et al., 2005), and seeking political cover to avoid pressure from regional stakeholders (Dilling et al., 2018)). To date, few studies have examined water managers' behavior through the lens of organizational theory, which is typically reserved for private sector firms.

Scholars of organizational theory treat organizations as behavioral agents (Berkhout, 2012) who, through private decision-making processes, interpret underlying weaknesses in existing practices (Carley \& Harrald, 1997) and optimize performance in response to perceived 
changes in the operating environment (Linnenluecke et al., 2012). Organizational theory scholars often employ the idea of sense-making (Maitlis \& Christianson, 2014), to characterize the social process by which organizations attach meaning to an unexpected or surprising event (Weick, 1995). Sense-making is generally conceived of as a process that is triggered by "cues", often in the form of a surprise or violation of expectations that prompts a need for explanation, due to the uncertain or ambiguous nature of the cue. Cues are interpreted to create a rational account of the world that enables action in the face of uncertainty or ambiguity (Maitlis, 2005). In order for a crisis or extreme event to trigger a cue, there must be a sufficiently large "discrepancy between what one expects and what one experiences" such that decision-makers "ask what is going on, and what they should do next" (Maitlis \& Christianson, 2014). The sense-making process resulting from the detection of a cue, however, is thought to be strongly shaped by organizational ideology, which is comprised of "beliefs about cause-effect relations, preference for certain outcomes, and expectations of appropriate behaviors" (Weick, 1995). While sense-making is generally conceived of as a messy, iterative, and non-linear process, the elements of the sensemaking process can generally be theorized as: 1 . The occurrence of a cue, propelling the organization into a state of needing an explanation; 2. Interpretation of the cue, which involves creating a rational explanation or account that serves as a basis for action, and 3. Construction of understanding of what needs to happen, setting the stage for action (Maitlis \& Christianson, 2014). Similar to the theorized behavioral stages of risk appraisal and adaptation widely applied to the individual adaptation context (Grothmann \& Patt, 2005), sense-making conceptualizes interpretation of a signal or risk as preceding the appraisal of response options, but also considers the sense-maker's own role in causing the extreme event to occur, thus bringing in the idea of responsibility into the appraisal process. 
While exogenous determinants of adaptive actions (Granderson 2014) and industryspecific behavioral norms (Lach et al., 2005; Rayner et al., 2005) are important to understanding adaptation behavior, especially for highly institutionally constrained decision-makers such as water managers (Berkhout, 2012), the adaptation community may gain additional insights by examining the behavioral dimensions of manager responses to extreme events in the context of their overall organization (Burch and Robinson 2007) and their broader network (Moynihan 2008, Muro and Jeffrey 2008, Page and Dilling 2019). After all, water systems often face a similar set of institutional constraints (Berkhout, 2012) and are guided by similar set of behavioral norms (Lach et al., 2005), yet react very differently to a similar set of circumstances. This parallels findings in the psychological literature that point out there are a range of factors that affect a person's perception of and response to risk and that can explain some of this variability, including emotion, cultural context, and recent events (e.g. Slovic and Peters 2006, Kahan et al. 2012, and Folkes 1988,). Using a comparative case study approach, this study examines the process by which water systems, as organizations or groups of decision-makers, interpret, draw insights from, and become motivated by their experiences with past extreme drought events, using the theorized process of sense-making as our analytical frame. The sensemaking framework allows us to observe organizational ideology as it manifests in "beliefs about cause-effect relations, preference for certain outcomes, and expectations of appropriate behaviors" (Weick, 1995). Our study focuses on five systems in the Western Slope region of Colorado, in the Rocky Mountain region of the United States.

In the next section, we summarize our methods (section 2) and case description (section 3). Next, we present a summary of the sense-making processes for each case and highlight key themes that emerge across the cases (section 4). We then present a discussion of how our 
findings a) problematize the window of opportunity hypothesis associated with extreme events, in particular the spatial and temporal dimensions of change, b) nuance our understanding of reliability and mitigating political tension as key motivations for water managers, and c) raise questions about the role of organizational ideology and outlook in shaping adaptation outcomes (section 5). We conclude with a discussion of limitations and future research directions (section $6)$.

\section{Methods}

We employed a comparative case study design for this study, which allows for identifying themes that emerge across multiple units of analysis (groups of decision makers within water system organizations) and for a broader understanding of the phenomenon of sensemaking from extreme events, beyond what a single case study design could offer (Yin, 2014). Data was collected through two rounds of field work in 2017. Semi-structured one-on-one interviews $(\mathrm{n}=14)$ were conducted with decision-makers (e.g. general managers, water engineers), across the five cases in spring 2017 and semi-structured focus group discussions (16 participants across 5 discussions; 2-5 participants per discussion) were conducted with each of the five case organizations in fall 2017. While the one-on-one interviews allowed us to capture in-depth individual perspectives on perceptions and concerns related to drought absent of group dynamics, the focus groups provided a venue for eliciting shared narratives across each organization about how past drought events have influenced organizational change. As sensemaking is inherently a social and interactive process (Maitlis \& Christianson, 2014), we chose a group discussion format to allow managers to collectively recall and reconstruct their sensemaking processes of past drought events. 
The criterion for inviting interviewees in the spring 2017 interviews was that individuals had to play some role in operational decision-making related to water supply and drought management. Snowball sampling was used to identify additional employees at each entity who fit this criterion; we were able to interview $100 \%$ of the employees recommended through this snowball sampling process. For the fall 2017 focus groups, criteria for inviting participants were that managers had to have been present for a past drought event and/or have had some perspective on how past droughts have affected some aspect of the organization, as well as have played some active decision-making role in managing drought (a slightly broader group than who participated in the interviews). We similarly asked our main points of contact at each organization to recommend a group of employees to participate in these focus groups, including administrative employees and attorneys who were employed at the organizations during past drought events. The organizations selected as cases are relatively small and each have as few as 2-5 active personnel tasked with management and decision-making related water supply and drought. Therefore, though our overall sample of interviewees $(n=14)$ and focus group participants $(n=16)$ is relatively small, we were able to capture the views and collective memories of the central decision-makers at each organization.

Interviews covered questions about general drought concerns, available drought measures, and constraints related to drought preparedness, as well as a handful of questions of individual managers' past experiences of drought. Focus group discussions were used to collect shared narratives of past experiences with drought, impacts from those past experiences, and lessons drawn and/or enacted from past experiences. Interviews and focus groups were recorded with participant consent and manually transcribed by the lead author; transcripts were coded using qualitative coding software NVivo (Bazeley \& Jackson, 2013). An open coding framework 
was developed to guide the data analysis process, based on a combination of a priori themes derived from relevant literature and emergent codes. For example, we used a set of a priori codes based on the theorized process of organizational sense-making: the cue (mention of specific characteristics of the event that were surprising and/or violated managers' expectations), cue interpretation (specific meaning, insight, or lesson attached to a specific cue), and construction of response (conclusions drawn by managers about specific actions or non-actions to take, as justified by cue interpretation).

While our unit of analysis is on the organization level, we recognize the risk that this introduces in "concealing the action of individuals operating within the organization" (Argyris \& Schon, 1996; Pelling et al., 2008) and strive to make clear any discrepancies between responses of individuals from the same organization. Using the organization as the unit of analysis acknowledges the fact that while motivation and sense-making is experienced and decisions are made by managers as individuals, within an organizational context these processes are "stored in and brought forth from organizational memory" (Diduck, 2010) and thus examining each group of managers as one unit of analysis is warranted. Obtaining multiple perspectives from individuals at each organization allowed us to look for the organizational perspective and ensured that we were not only obtaining one individual's perspective.

Finally, we acknowledge that responses that arise from experience of an extreme event invariably have "multiple points of origin" (Birkmann et al., 2010) and that any organizational action purportedly motivated by a specific extreme event is also likely to come about as result of either institutional/political influences unrelated to the event (Berkhout, 2012; Penning-Rowsell et al., 2006). We acknowledge this limitation and base our analyses on actions our study participants' judge to be attributable to a specific extreme event, as other scholars examining 
event-induced change have done in the past (Penning-Rowsell et al., 2006). In addition to responses and actions relating to the direct effects of drought (reductions in water supply), we include the role of secondary effects of drought in our analysis of drought-induced actions, such as the occurrence of wildfire or unintended consequences of drought-related user behavior. Given that significant time has passed between these events and the time of data collection, we do not assume that narratives shared by the managers are 'complete' - we are ultimately concerned with how managers interpret and make sense of past events in the larger context of their organizational outlooks and contexts.

\section{Case Description}

\section{a. Colorado Western Slope}

This study focuses on Colorado's Western Slope region, which encompasses much of the Upper Colorado River Basin (UCRB). The UCRB originates in the headwaters region (Livneh et al., 2015) where the hydrology can be categorized as snowmelt dominated, with complex topography (Livneh et al., 2014). The principal economic sectors across the Western Slope include ranching, irrigated agriculture, natural resource development, recreation, tourism, and mining, which are all tied to water (Gordon \& Ojima, 2015). The Western Slope region, like the rest of the Upper Colorado River Basin, contains relatively little storage as compared to other areas in the western U.S., making water users across the region highly sensitive to inter-annual hydrologic variability and specifically drought (Callihan, 2013).

Much of the water originating from the Western Slope is allocated for use elsewhere, either via the Colorado River to meet water demands of other states downstream, or routed through trans-mountain diversions that bring water to the more populous and agriculturally 
intensive areas of eastern Colorado, including the Denver metro area. The Western Slope can thus be vulnerable to drought in two ways-directly, through lack of precipitation and surface water supply on the local scale and indirectly through drought outside the region that produces a higher demand for water elsewhere. The Western Slope, like the rest of the state of Colorado, is governed by the prior appropriation system, a legal system that gives senior water rights priority over more junior water rights; seniority is determined by the time when the water rights were purchased (Getches, 1990). During a drought, the priority of rights can lead to some users receiving less water as senior users place a "call" on the river. Future water demand is expected to triple across the Colorado River Basin by 2060, with the majority of that demand coming from the municipal and industrial sectors (Gordon \& Ojima, 2015). Simultaneously, climate change is expected to cause earlier snowmelt and peak runoff (Ibid.).

\section{b. Western Slope Community Water Systems (CWSs)}

A large number of small community water systems (CWSs) exist throughout the Western Slope that develop, manage, and supply water for domestic, industrial, agricultural, and environmental uses. Water systems have long dealt with the high hydrologic variability that occurs from year to year across the Western Slope as well as across the broader western U.S. (Bales et al., 2006). An assumption of hydro-climatic variability is "baked into" all aspects of water management decision-making, from managing reservoir operations to balance current needs with future risk of shortage, to calculating and planning for a water system's 'firm yield', i.e. 'the volume of water guaranteed with acceptable shortage' (Srijevic et al., 2004). While Western Slope water systems have distinct service district boundaries and utilize unique combinations of water supply sources from different drainages, many of them are hydrologically 
interdependent with other regional water users and stakeholders, often requiring coordination and collaboration in times of shortage (McNeeley, 2014; Ray, 2004).

We selected five water systems across Colorado's Western Slope region to examine in this comparative case study. The selected systems generally represent the range of systems found throughout the Western Slope region, which supports a large agricultural sector, industry, power production, recreation, as well as a growing population of small cities and towns. Local water systems across the Western Slope include municipal utilities, regional retail water suppliers, wholesale water suppliers (such as water conservancy districts), and ditch companies. The amount of storage available to these entities is also varied, with some entities managing and benefiting from large federal reservoirs, and some entities depending solely on snowpack as their form of storage. Only about 500,000 of the state's approximately 5.7 million residents live on the Western Slope and are widely distributed, with Grand Junction being the largest population center at about 60,000 people. Water systems found throughout the Western Slope are generally smaller (in terms of number of people served and/or GDP of agricultural activity supported through supplying irrigation water) and lower capacity (in terms of the number of staff) than the large municipalities and irrigation districts found throughout the more densely populated east slope of Colorado. For example, even the largest domestic water provider in the Western Slope region only serves 80,000 people and delivers 10,000 acre-feet of water annually, and the smallest with orders of magnitude fewer customers or acre-feet delivered (Lowrey et al., 2009). Western Slope water entities range widely in size in terms of customers, acres of irrigated land served or acre feet delivered, and thus there is no "typical" water entity. Table 1 summarizes key characteristics of the five case studies.

[Table 1] 


\section{c. 2002 and 2012 droughts}

In the early 2000s, Colorado experienced a multi-year drought event that has been described as "the worst drought in Colorado history", due to a combined effect of high temperatures, low precipitation, and higher than average water demands (Pielke et al., 2005). The drought began during a dry fall and winter in 1999, followed by multiple consecutive dryer-thannormal years, peaking in 2002. This extended dry period resulted in an exceptionally long wildfire season, widespread water shortages, severe crop losses, and adverse environmental impacts. The 2002 drought resulted in a number of legislative changes. For example, the drought illuminated the need for water users to be able to transfer water quickly in times of critical shortage without seeking judicial approval as is required under normal conditions (Kuranz, 2014). New legislation was passed in the years after the drought allowing water users to temporary loan water for instream flows (i.e. Short Term Leasing (STL)) without risking their own water rights. The next dry period experienced in Colorado began in the spring and early summer of 2012 and extended into the spring of 2013 for some areas (McNeeley et al., 2016). The 2012-13 drought was not as persistent as the early 2000s multi-year drought but resulted in water shortages and agricultural damage in many parts of the state (Ibid). The first STL for instream flows was implemented during the 2012-13 drought (Kuranz, 2014). U.S. Drought Monitor Maps from the 2002 and 2012 droughts are presented in figure 1.

[Figure 1]

\section{Results}


As described one by manager, every drought has a unique "signature" (case 1). Indeed, each group of managers across the five systems experienced the droughts of 2002 and 2012 in unique ways. Generally speaking, the 2002 drought had a larger impact on the five water systems than the 2012 drought, with the 2012 drought serving as an opportunity for some managers to test out and receive feedback on organizational adjustments and system improvements made in the aftermath of 2002. We present four key findings that emerge from a cross-case analysis of drought narratives and the sense-making processes of the five systems.

\section{Finding 1. Competing constituent demands produce the most pressure for managers during drought.}

Across the five cases, stakeholder pressure related to protecting and prioritizing different water uses was a major source of stress and concern, in most cases more so than the actual implementation of drought response measures. During drought events, competition over water uses increased, and constituents expected managers at water systems to protect their particular uses, including consumptive and non-consumptive uses. One group of managers (case 4) described the "ongoing miscommunication and misinformation" with downstream residents who were concerned about low streamflow in their local creeks. Another group of managers (case 1) described stakeholder pressure as follows:

No good deed goes unpunished. We've experience it this year and other years, no matter what you do, no matter how flexible you try to be, someone will criticize. (case 2)

Some systems experienced additional sources of surprise, stress, and concern that were either not directly related to water shortages (e.g. operational issues unrelated to the drought itself (case 4, case 2)) or a secondary effect of drought and drought-related behavior (e.g. subsidiary demands on water supply caused by occurrence or risk of wildfire in the area (case 4, case 5); financial 
impacts of conservation efforts (case 5)). These additional sources of stress compounded the fundamental challenges associated with physical shortage of water supply and implementation of drought response measures. In describing these compounding factors, managers referred to their drought experiences as "the perfect storm" (case 4, 5), "bad timing" (case 2), and a "pressure cooker" (case 4).

\section{Finding 2: Extreme events can sometimes motivate adaptive response, especially when system reliability is threatened}

During the drought of 2002, though managers at the five systems encountered unique stresses, surprises, and concerns, they had similar experiences in terms of facing the first major drought in the region in 25 years with underdeveloped drought management systems and/or relying heavily on off-the-cuff response measures. Two of the domestic water providers (case 4, 5), described having existing drought management plans in place going into the drought that had "been sitting on the shelf" (case 5) and that they "had never really used before" (case 4).

We found that three of the cases we examined (case 1,3,5) demonstrated sense-making processes that align with the "window of opportunity" hypothesis, in which managers' experiences of past drought revealed underlying system weaknesses that then motivated them to make improvements and expand or adjust their available drought measures. In other words, managers' experiences of drought prompted their organizations to adapt and in turn reduce their vulnerability to a future drought event. The cues (i.e. sources of surprise) detected and interpreted by managers of each of the systems revealed that threats to system reliability, specifically to water supply reliability, was a central concern and trigger for adaptation appraisal processes. These threats manifested as either dealing with the risk of not successfully filling 
reservoirs, or managing the lack of formal mechanisms to reduce consumption. Both types of threats fundamentally related to managers' ability to balance supply and demand and maintain available water supply throughout the drought event.

The managers at case 3 "had never really thought about [shortage] before" and in 2002 were faced for the first time with the risk of agricultural and well users in their district being curtailed by downstream senior rights holders (their "cue"). In terms of interpreting this cue, managers at this system looked inward at their own systems and concluded that "the systems we had in place weren't functioning properly”. Managers took a number of adaptive actions to address the underlying system vulnerabilities that emerged from their experience in the drought. The most significant changes made by managers at this organization were that they purchased and built new reservoir storage and created a "new role" for their organization: selling augmentation plans to well users with whom the district had previously not engaged as a customer base. The new storage, which holds replacement water that is released in times of shortage to offset the diversions made by well users, was critical to allowing well users in their district to continue to divert water and to avoid curtailment in the 2012-13 drought. Managers at case 3 provide a clear example of how experience of drought can illuminate and provide an opportunity for addressing underlying system vulnerabilities related to water supply reliability.

For managers at case 5, their "cue" from the 2002 drought was related to their supply and demand curves coming close to crossing and the fact that they had no mandatory mechanism in place to reduce water consumption among their customers. Similar to managers at case 3 , the managers at case 5 interpreted these cues by turning inward to examine their own processes. First, they determined that they were "too reliant on surface supplies.” Secondly, the informal "reward structure" they had in place to incentivize conservation turned out to be worse than 
ineffective, amounting to a "headache" for the water entity, and a "great expense". Ultimately, these managers took a number of adaptive actions to address these issues, including developing groundwater sources and introducing new mechanisms for encouraging conservation (tiered rate system) and reducing demand during drought events (drought surcharges). Similar to managers of case 3 , these managers directly drew from their experiences in the 2002 drought to making organizational adjustments that allowed for shoring up reliability in future drought conditions and ultimately allowed them to handle the next drought of 2012-13 with more ease.

Like managers in case 3 and 5, managers in case 1 were motivated by their experience of drought to make adjustments, but instead of changing supply or demand, case 1 managers changed their sources of drought information. The managers we interviewed at case 1 had long desired to improve the scientific information and decision-support tools they depend on to increase accuracy in reservoir operations. Though the current managers were either not present or in decision-making roles during the 2002 drought, they maintain a clear narrative of the "cue" from their district's experience during the 2002 drought, when the reservoir did not fill. Specifically, they critiqued the previous decision maker's tendency to rely on simple average hydrologic conditions to make decisions, stating he was "comfortable getting [reservoir management] wrong half of the time". Conversely, the managers we interviewed "had a different expectation of the science [they] could use" to inform their reservoir operations, and specifically concluded that they "needed [their own] operational model". During the 2012 drought the reservoir did not fill for the first time during their time as key decision-makers at the organization, which created a sense of urgency to "to figure out this drought management stuff right away" and drove them to seek a more accurate decision support tool for their needs. The 2012 drought experience ultimately motivated them to build a snowpack-based operational 
model that is "more conservative than relying upon early season forecasts" but better suits their information needs.

\section{Finding 3: Not all impacted systems take action, and not all systems that take action are impacted}

We also found that among those water systems that were negatively impacted by a past drought event, managers from one system (case 4) have not made any major changes since the drought in terms of their supply or demand management measures. Simultaneously, we found that among those systems that took notable adaptive actions in reaction to a past drought event, one of those systems (case 2) was not actually directly impacted at all by the 2002 or 2012 droughts in terms of needing to implement restrictions, draw on backup sources, or implement other major response measures.

The managers at case 4 described their experience of the 2002 drought as "a worst case scenario". Many things "went wrong” for their system, including a local wildfire that increased demand for fire protection water and threatened some of their water system infrastructure, operational failures, and misunderstanding and tension with customers and constituents over drought restrictions and flow levels in local waterways. One particularly salient cue from the 2002 drought was their experience implementing use restrictions (odd-even outdoor watering days) for the first time, only to see an increase in water consumption by their customers as they used water driven by their assigned entitled use day, rather than actual need. The managers ultimately interpreted this cue as evidence that their prior assumptions of "what [their] customers are likely to do" in reaction to use restrictions were "prove[n] wrong”.

Despite this "worst case scenario", upon reflecting on the overall experience, managers felt they "did a pretty good job" managing the drought and were "just glad [they] survived"; 
"nobody died" from the more acute threats (wildfire); and other entities in their sub-basin struggled more than they did and even "called [them] to see what [they] were doing".

Ultimately, these managers interpreted their experience during the 2002 drought as having "dodged a bullet" and concluded that, in spite of the challenges with increased consumption by customers and other operational issues, they were sufficiently prepared for a worst case scenario because they did not need to tap into their emergency water supply source. As one manager put it:

That's why there haven't been any changes...because we went through a worst case scenario, and still we had something in our back pocket. (case 4)

As for learning from their experience implementing use restrictions, managers have taken actions to promote awareness of drought and conservation among their customers in the hopes that the same customer response would not happen in a future drought. However, since the 2002 drought, they have actively avoided implementing restrictions out of fear of repeating their experience in 2002:

We had some years that were close, but, we chose not to go down that road again, because of our experience in 2002. We're going to have to wait it out and see.

Another manager explained that he "doesn't even know" what it would take to "pull the trigger again". Ultimately, these managers have taken actions to address the underlying issue of conservation awareness, but have resisted taking actions that would allow them to evaluate whether their awareness raising efforts have been effective in achieving desirable use restriction outcomes.

Case 2, on the other hand, reacted very differently to a similar "cue" of not being strongly impacted by the drought. At case 2, as one manager explained, they "were literally fine" throughout the 2002 drought and "kind of breezed by", in contrast to other entities throughout 
the region that "didn't do as well" in comparison. Managers at case 2 explained that the 2002 drought showed them that the "homework" they had done between the previous drought of 1977 and the drought of 2002 allowed them to "[get] through it with no skin off [our] nose" and confirmed that they were prepared for a 2002-type drought. Despite the fact that their system was not at all impacted by the drought, they still saw the 2002 drought as "an eye opener" in terms of increasing their awareness of the need to "stay ahead of the curve" and continue to diversify and grow their water supply sources as they had continuously worked on since the prior 1977 drought. As one manager explained: "[The 2002 drought] reinforced that we need to continue to buy water [rights] when it becomes available...We better be diligent."

Notably, these divergent conclusions about the need to use backup or emergency water sources are mirrored by distinct differences in the two groups' organizational outlook and sense of responsibility related to regional drought risk. For example, managers at case 2 , in describing their rationale behind their aggressive water planning strategy, emphasized their interest in maintaining their own legacy as managers and in leaving their system better than they found it: “We don't want to leave here in fifty years from now, someone cussing us, because we didn't' buy enough water" (case 2). Another manager rationalized their forward-looking water supply planning as a way of mitigating overall drought risk and ensuring their own protection in the event that others in their region suffer shortages:

There's no one out here that can help us. We can help them, we're bigger, they're going to look us, we're their back up...There's nobody here that's going to rescue us. (case 2) Managers at case 4 spoke to a very different outlook on their role in mitigating regional drought risk and their strategy for ensuring their own preparedness. In explaining why they generally are not looking to expand their water supply sources, one manager at case 4 explained: 
Certainly we have a finite supply and a finite ability to provide both domestic [water] and fire protection [water]. So, we don't try to be everything to everybody. We know that we've got some limitations, and we try to be reasonable about what we take on. (case 4)

Contrary to the managers at case 2 , managers at case 4 are mitigating their drought risk not by taking on others' drought risk but by focusing inwards and setting boundaries around how much they're willing to accommodate increasing water demands in their area. These insights into each groups' approaches to mitigating risk and outlooks on regional responsibility help to explain their drastic differences in responses to the 2002 drought.

\section{Finding 4: Political pressure alone can motivate action, and political motivations can both help and hinder drought adaptation outcomes}

We also found that, for one group of managers (case 2), political pressure alone was enough to motivate them to make significant investments in demand management. As described above, this system was not impacted by the 2002 drought (they "breezed by") and was driven to invest in augmenting and diversifying their water supply after seeing the impacts the drought had on neighboring communities and out of a desire to "stay ahead of the curve". However, in terms of demand management, these managers were purely motivated by a desire to deflect political pressure they received from entities throughout the region because it was perceived that case 2 “didn't do enough" and did not implement use restrictions while other communities were suffering. As one manager put it, case 2 managers were "getting heat" from other water systems higher up in their watershed and they wanted to "do something" to "shut them up". Their tactic for mitigating this pressure was to form an alliance with three other water entities in their subbasin and form a regional drought plan that dictates all four systems' drought measures such that if one system faces shortage, they all implement drought restrictions in a coordinated fashion. 
Though the impetus for forming this alliance was to mitigating political pressure that arose from other entities during the 2002 drought, the managers expressed that the alliance "has been really good" and has been effective in both staving off political pressure and helping the systems to build better rapport and relationships in general.

Moreover, we found that motivation based in avoiding political pressure can both enhance and hinder drought preparedness. For case 2 (described above), managers forged a regional partnership and developed a regional drought plan, out of a desire to reduce political pressure from regional stakeholders. Though this action was politically motivated, the regional drought plan has been very successful in building their own drought preparedness as well as advancing their sub-basin's overall resilience to drought. As one manager explained, "when one of us has a problem, we all have a problem", which he felt was an important perspective to have in building regional preparedness.

On the other hand, managers at case 4 provide an example of how motivation based in avoiding political pressure, in their case tension and push back from customers, can result in avoidant behavior that postpones taking measures to address drought vulnerabilities. As described above, managers at case 4 have avoided implementing use restrictions out of fear of customers increasing their water use as they had in 2002. However, in addition to their concerns about a physical inability to lower their water demand curve in a time of crisis, their ongoing decisions to avoid implementing use restrictions is also motivated by a desire to avoid political pressure from their customers, specifically the "pushback" and "miscommunication" that posed a significant challenge to them during the 2002 drought. For both systems (case 2 and 4), averting political tension was a motivating factor that has heavily influenced the actions they have chosen to take (or not) in the aftermath of past drought experiences, and demonstrate that, 
as a motivating factor, avoiding political attention can both serve to boost and hinder overall drought preparedness.

\section{Discussion}

By shedding empirical light on specific, organization-level sense-making processes that arose out of past drought events across five water systems, this study helps to nuance our understanding of the role of extreme events in driving adaptation, the processes by which water managers become motivated to adapt, and the ways that different types of motivation and organizational outlook and ideology influence drought adaptation outcomes.

\section{a. Extreme events as a driver of adaptation}

First and foremost, our findings confirm that extreme events do not consistently drive adaptive change in these small water systems, but that they can. We did find that three of our cases showed examples of learning from droughts over time, consistent with the hypothesis that extremes can sometimes prompt learning, and thus serve as "pacemakers of adaptation" that help to build resilience (Travis 2014). However, we saw two examples of water systems that did not follow the linear conceptual models of event-induced change in which extreme events reveal vulnerabilities that can then be systematically addressed (Carley \& Harrald, 1997) or in which impacts of an extreme event lead to change (Birkmann et al., 2010). Managers from a system (case 2) that experienced no negative impacts from a drought were prompted to make significant investments in water supply augmentation and diversification, and managers from a system (case 4) that experienced notable hardship during the 2002 drought did not feel motivated to make changes after the experience because they interpreted their survival of the event as confirming 
their own preparedness. Our finding that political pressure alone can motivate adaptive actions among managers also nuances the idea that impacts of a disaster leads to change (Birkmann et al., 2010) - one of our cases (case 2) shows how regional impacts can drive change at the organizational level among organizations that were not impacted, via political pressure to proactively participate in regional drought management and recovery efforts.

\section{b. Dynamics of drought adaptation}

In addition, the fact that one of our cases (case 2) was not directly impacted by the 2002 drought but still implemented substantial adaptive actions (e.g. supply augmentation, regional drought plan) in the years following the drought, suggests that actions driven by extreme events may not occur in space and time as we would expect from theory of change models suggested by Birkmann et al. (2010). Adaptations may appear in unexpected places or at unexpected times for case 2, the culture of responsibility that arose out of a 1977 drought manifested in a renewed motivation and an additional set of adaptive actions nearly thirty years later during a subsequent drought event. Moreover, our results suggest that some water managers in the Western Slope region share a sense of responsibility to address drought that binds them together and results in an expectation to act collectively in response to drought despite who is impacted and who is not. Studies have documented similar types of collective approaches to drought management in the region (McNeeley et al., 2016) among water systems trying to avoid curtailment within the same sub-basin, but our results reveal that water systems may put pressure on each other to act in times of drought for a less tangible goal such as solidarity. It may be the case that the peer pressure that arose for managers at case 2 was also practically and politically tied to the Western Slope water systems' collective responsibility to keep enough water flowing downstream to the lower 
Colorado River Basin to meet the obligations of the Colorado River Compact, even in times of local shortage. Understanding specific motivations behind this pressure is beyond the scope of this study. Still, our results suggest that political and hydrologic inter-dependencies among water systems may result in non-linear, dynamic drought adaptation processes that may be more difficult to track in time and space than the typical theory of change behind extreme events might suggest (Henderson et al., in prep., Dilling et al. 2015).

\section{c. Mitigating political tension as a mediator of drought adaptation outcomes}

Our results also shed light on the factors that specifically motivate water managers and how those factors interact with drought preparedness goals. Our results confirm that system reliability (Hashimoto et al., 1982; Lach et al., 2005) and mitigating political pressure (Dilling et al., 2018; Hornberger et al., 2015; Kirchhoff and Dilling 2016) are major motivating factors for water managers and feature significantly within the causal pathway that connects experience of extremes with adaptive action. However, our results also help to add nuance to an otherwise established literature on motivation within water management, by illustrating how these motivations, specifically political motivation, can interact with adaptation outcomes in different ways, depending on how managers makes sense of and draw lessons from political pressure received during an event. We see in our results an example of managers facing political pressure arising from a specific drought context and concluding that it is in their best interest to take go above and beyond what was immediately called for by political pressure, such as forging a regional alliance and coordinated drought plan with other local systems and "operating as one system". Yet, for another system, managers' interpreted the political pushback and negative attention placed on their adaptive actions (use restrictions) as a lesson about their users' 
seemingly immutable disposition regarding use restrictions regardless of circumstance, and have avoided implementing use restrictions ever since, regardless of the context. These results help to illustrate how a desire to mitigate political tension that arises during drought events, a known motivation among water managers, can shape and influence drought adaptation in varying ways, depending on how managers interpret and draw lessons from the political pressure, and in some cases can help to explain a lack of adaptive action and persistence of avoidant behavior.

\section{d. Explaining differential adaptation outcomes with organizational ideology}

Lastly, our results raise important questions about the role of organizational outlook and ideology related to risk and responsibility as a potential explanatory factor for understanding why water systems act differently in reaction to similar drought circumstances. Organizational ideology is considered to play a central role in sense-making and in shaping what organizational decision-makers "see" in terms of acceptable actions in response to a cue (Berkhout, 2012; Linnenluecke et al., 2012); in this study we see specifically the role of perceived responsibility for regional drought risk as a type of ideology that influences managers' risk management strategies and appraisal of post-drought responses. While one group of managers demonstrated a strong sense of leadership and obligation to lead the region on proactive adaptation (case 2), another group of managers emphasized their limitations and lack of desire to take on a larger role in supporting the region's adaptation to changing conditions and water supply needs. While other factors undoubtedly play a role in shaping these managers' differing responses, such as organizational scale (e.g. case 2 is the largest water supply system in their region, and their size and capacity relative to other similar systems in the region likely plays a large role in shaping their sense of responsibility in dealing with drought), access to financial resources, and different 
management priorities between conservancy districts and municipal water providers, our results suggest that the socio-cognitive dimension of ideology and outlook may also play an important role in influencing adaptation outcomes.

\section{Conclusion}

Extreme events are often theorized as providing "windows of opportunity" for addressing determinants of climate risks and reducing societal vulnerability to climate variability. Extreme events are commonly discussed as a key driver of adaptation, but the extent to which this bears out in reality is contested. Deepening our understanding of when and how adaptations to climate variability unfold today is important for a) revising societal expectations that progress autonomously evolves from the occurrence of extreme events and b) predicting how adaptation will occur in a future climate in which frequency and magnitude of extremes are predicted to increase. This study contributes sector-specific empirical descriptions of how extreme events influence adaptation on the organizational level and deepens our understanding of what motivates water management organizations to adapt to drought. Though our results are not generalizable to all water managers, our findings raise important questions about the linear assumptions behind event-induced change in which impacts and adaptation are linked together and in which impacts of extreme events lead to a broadening of drought measures, tools, and information. In addition, we find that political motivations that often drive decision-making among water managers can both help and hinder drought adaptation process and that the political forces that bind water systems together across a region may cause adaptation progress to happen more quickly due to an expectation of collective action in the face of drought risk. Our results 
also raise important questions about the potential role that organizational ideology and outlook, specifically beliefs about risk and responsibility, plays in influencing adaptation outcomes.

Additional research examining a larger population of water systems would allow for further testing and validation of the questions and observations raised here. In addition, in this study we specifically examine rural water systems; it may be interesting to compare rural water systems with larger municipal systems to better understand the role that organizational scale might play in shaping how managers react to and think about drought risk. Similarly, examining a more homogenous group of water systems (e.g. all municipalities or all irrigation districts) would allow for controlling for operational mandates and management priorities, which vary drastically between a municipal domestic water supplier and a wholesale irrigation district (for example) and which may play a role in how managers make sense of drought experiences. Future research in this area should also more systematically examine the role of organizational ideology and outlook in shaping collective conceptions of appropriate adaptations. Ultimately, this study helps to nuance existing theory behind extremes as a driver of adaptation as well as contributes important practical context for state agencies and other types of organizations interested in finding windows of opportunity to support local water systems to build drought preparedness.

\section{Acknowledgments}

We thank all of the Western Slope water managers who gave of their time to participate in this study. The authors gratefully acknowledge support from the National Oceanic and Atmospheric Administration's Sectoral Applications Research Program under grant \# NA16OAR4310132, Ben Livneh, PI. We are also grateful to Eric Kuhn of the Colorado River District, Nolan Doesken of the Colorado Climate Center, and Jeff Lukas of the Western Water Assessment for 
providing valuable feedback and input into the design of this study. The authors are solely responsible for all content.

\section{Literature Cited}

Argyris C, Schon D (1996) Organizational learning II: Theory, Method, and Practice. Reading, UK: Addison-Wesley

Bales RC, Molotch NP, Painter TH, Dettinger MD, Rice R., Dozier J (2006) Mountain hydrology of the western United States. Water Resources Research, 42, W08432. https://doi.org/10.1029/2005WR004387

Bazeley P, Jackson K (2013) Qualitative Data Analysis with NVivo. Sage Publications Limited

Beckert J (1999) Agency, Entrepreneurs, and Institutional Change. The Role of Strategic Choice and Institutionalized Practices in Organizations. Organization Studies, 20(5), 777-799

Berkhout F (2012) Adaptation to climate change by organizations. Wiley Interdisciplinary Reviews: Climate Change, 3(1), 91-106. https://doi.org/10.1002/wcc.154

Birkland TA (2006) Learning from Disaster: Policy Change after Catastrophic Events. Georgetown University Press

Birkmann J, Buckle P, Jaeger J, Pelling M, Setiadi N, Garschagen M, ... Kropp, J (2010) Extreme events and disasters: a window of opportunity for change? Analysis of organizational, institutional and political changes, formal and informal responses. Natural Hazards, 55, 637-655. https://doi.org/10.1007/s11069-008-9319-2

Burch S, Robinson J (2007) A framework for explaining the links between capacity and action in response to global climate change and action in response to global climate change. Climate Policy, 7(4), 304-316

Burnham M, Endter-Wada J, \& Bardsley T (2016) Water Management Decision Making in the Face of Multiple Forms of Uncertainty and Risk. Journal of the American Water Resources Association, 1-19. https://doi.org/10.1111/1752-1688.12459

Busenberg GJ (2001) Learning in Organizations and Public Policy. Journal of Public Policy, 21(2), 173-189

Callihan LM (2013) A robust decision-making technique for water management under decadal scale climate variability. University of Colorado Boulder Dissertation 
Carley KM., Harrald JR (1997) Organizational Learning Under Fire: Theory and Practice. American Behavioral Scientist, 40(3), 310-332

Christoplos I (2006) The elusive "window of opportunity" for risk reduction in post-disaster recovery. In ProVention Consortium Forum (pp. 1-4)

Diduck A (2010) The Learning Dimension of Adaptive Capacity: Untangling the Multi-level Connections. In D. Armitage \& R. Plummer (Eds.), Adaptive Capacity and Environmental Governance (pp. 199-222). Springer

Dilling L, Daly M, Kenney D, Klein R, Miller K, Ray A, Wilhelmi O (2018) Drought in urban water systems: Learning lessons for climate adaptive capacity. Climate Risk Management. https://doi.org/10.1016/j.crm.2018.11.001

Dilling L, Daly M, Travis W, Wilhelmi O and R Klein 2015 The dynamics of vulnerability: Why adapting to climate variability may not always prepare us for climate change. WIREs: Climate Change 2015. DOI: $10.1002 /$ wcc. 341

Dilling L, Pizzi E, Berggren J, Ravikumar A, Andersson K (2017) Drivers of adaptation: Responses to weather- and climate-related hazards in 60 local governments in the Intermountain Western U.S. Environment and Planning A, 0(0), 1-21. https://doi.org/10.1177/0308518X16688686

Endter-Wada J, Selfa T, Welsh LW (2009) Hydrologic Interdependencies and Human Cooperation: The Process of Adapting to Droughts. Weather, Climate, and Society, 1(1), 54-70. https://doi.org/10.1175/2009WCAS1009.1

Engle NL (2013) The role of drought preparedness in building and mobilizing adaptive capacity in states and their community water systems. Climatic Change, 118(2), 291-306.

https://doi.org/10.1007/s10584-012-0657-4

Feldman DL, Ingram HM (2009) Making Science Useful to Decision Makers: Climate Forecasts, Water Management, and Knowledge Networks. Weather, Climate, and Society, 1, 9-21. https://doi.org/10.1175/2009WCAS1007.1

Folkes, V. S. (1988). The availability heuristic and perceived risk. Journal of Consumer Research, 15(1), 13-23.

Getches, DH (1990) Water Law in a Nutshell. St. Paul: West Pub. Co.

Glenk K, Fischer A (2010). Insurance, prevention or just wait and see? Public preferences for water management strategies in the context of climate change. Ecological Economics, 69(11), 2279-2291. https://doi.org/10.1016/j.ecolecon.2010.06.022 
Gober P (2013) Getting Outside the Water Box: The Need for New Approaches to Water Planning and Policy. Water Resources Management, 27(4), 955-957.

https://doi.org/10.1007/s11269-012-0222-y

Gordon E, Ojima D (2015) Colorado Climate Change Vulnerability Study. A report submitted to the Colorado Energy Office. Retrieved from http://wwa.colorado.edu/publications/reports/co_vulnerability_report_2015_final.pdf

Granderson AA (2014) Making sense of climate change risks and responses at the community level: A cultural-political lens. Climate Risk Management, 3, 55-64.

https://doi.org/10.1016/j.crm.2014.05.003

Grothmann, T, Patt, A (2005) Adaptive capacity and human cognition: the process of individual adaptation to climate change. Glocal Environmental Change, 15(3), 199-213.

https://doi.org/10.1016/j.gloenvcha.2005.01.002

Hashimoto T, Stedinger JR, Loucks DP (1982) Reliability, resiliency, and vulnerability criteria for water resource system performance evaluation. Water Resources Research, 18(1), 14-20. https://doi.org/10.1029/WR018i001p00014

Hornberger GM, Hess DJ, Gilligan J (2015) Water Conservation and Hydrological Transitions in Cities in the United States. Water Resources Research, 51, 4635-4649.

https://doi.org/10.1002/2016WR019804

Huitema D, Meijerink S (2010) Realizing water transitions: the role of policy entrepreneurs in water policy change. Ecology and Society, 15(2), 26

Jacobs K, Pulwarty R (2003) Water Resource Management: Science, Planning, and DecisionMaking. In R. Lawford, D. Fort, H. Hartmann, \& S. Eden (Eds.), Water: Science, Policy, and Management (pp. 177-204). American Geophysical Union

Kahan, D. M., Peters, E., Wittlin, M., Slovic, P., Ouellette, L. L., Braman, D., \& Mandel, G. (2012). The polarizing impact of science literacy and numeracy on perceived climate change risks. Nature Climate Change, 2(10), 732-735. doi:10.1038/nclimate1547

Kiparsky M, Milman A, Vicuna S (2012) Climate and Water: Knowledge of Impacts to Action on Adaptation. Annu. Rev. Environ. Resour, 37, 163-196. https://doi.org/10.1146/annurevenviron-050311-093931

Kirchhoff, C. J., \& Dilling, L. (2016). The role of U.S. states in facilitating effective water governance under stress and change. Water Resources Research, 52(4), 2951-2964.

doi:10.1002/2015wr018431

Kirchhoff CJ, Lemos MC Dessai S (2013) Actionable Knowledge for Environmental Decision Making: Broadening the Usability of Climate Science. Annu. Rev. Environ. Resour, 38, 393414. https://doi.org/10.1146/annurev-environ-022112-112828 
Klein R, Kenney DS (2006) Use of Climate Information in Municipal Drought Planning in Colorado. Western Water Assessment White Paper

Kuranz A (2014) Multi-Level Collaborative Management of Colorado's Instream Flow Program. University of Colorado Boulder Dissertation

Lach D, Ingram H, Rayner S, Wise WA, Library L (2005) Maintaining the Status Quo: How Institutional Norms and Practices Create Conservative Water Organizations. Texas Law Review, $83,2027-2054$

Linnenluecke MK, Grif A, Winn M (2012) Extreme Weather Events and the Critical Importance of Anticipatory Adaptation and Organizational Resilience in Responding to Impacts. Business Strategy and the Environment, 21, 17-32. https://doi.org/10.1002/bse.708

Livneh B, Deems JS, Buma B, Barsugli JJ, Schneider D, Molotch NP, ... Wessman, C. A. (2015) Catchment response to bark beetle outbreak and dust-on-snow in the Colorado Rocky Mountains. Journal of Hydrology, 523, 196-210. https://doi.org/https://doi.org/10.1016/j.jhydrol.2015.01.039

Livneh B, Deems JS, Schneider D, Barsugli J, Molotch N (2014). Filling in the gaps: Inferring spatially distributed precipitation fromgauge observations over complex terrain. Water Resources Research, 50, 8589-8610. https://doi.org/10.1002/2014WR015442

Lukas J, Barsugli JJ, Doesken N, Rangwala I, Wolter K (2014) Climate Change in Colorado: A Synthesis to Support Water Resources Management and Adaptation. Available online at: https://wwa.colorado.edu/climate/co2014report/Climate Change CO Report 2014 FINAL.pdf (last accessed September 13, 2019)

Maitlis S (2005) The Social Processes of Organizational Sensemaking. The Academy of Management Review, 48(1), 21-49

Maitlis S, Christianson M (2014) Sensemaking in Organizations: Taking Stock and Moving Forward. Academy of Management Annals, 8(1), 57-125.

https://doi.org/10.1080/19416520.2014.873177

McNeeley SM (2014) A “toad's eye” view of drought: Regional socio-natural vulnerability and responses in 2002 in Northwest Colorado. Regional Environmental Change, 14(4), 1451-1461. https://doi.org/10.1007/s10113-014-0585-0

McNeeley SM, Beeton TA, Ojima DS (2016) Drought Risk and Adaptation in the Interior United States: Understanding the importance of local context for resource management in times of drought. Weather, Climate, and Society, 8, 147-161. https://doi.org/10.1175/WCAS-D-150042.1

Moynihan DP (2008) Learning under Uncertainty: Networks in Crisis Management. Public Administration Review, 68(2), 350-365. https://doi.org/10.1007/s11269-006-9040-4 
Muro M, Jeffrey P (2008) A critical review of the theory and application of social learning in participatory natural resource management processes. Journal of Environmental Planning and Management, 51(3), 325-344. https://doi.org/10.1080/09640560801977190

O'Brien KL, Wolf J (2010) A values-based approach to vulnerability and adaptation to climate change. WIREs Clim Change, 1, 232-242. https://doi.org/10.1002/wcc.30

O’Connor RE, Yarnal B, Dow K, Jocoy CL, Carbone GJ (2005) Feeling at risk matters: Water managers and the decision to use forecasts. Risk Analysis, 25(5), 1265-1275. https://doi.org/10.1111/j.1539-6924.2005.00675.x

Page, R., \& Dilling, L. (2019). The Critical Role of Communities of Practice and Peer Learning in Scaling Hydroclimatic Information Adoption. Weather, Climate, and Society, 11(4), 851-862. doi:10.1175/wcas-d-18-0130.1

Pelling M, High C, Dearing J, Smith D (2008) Shadow spaces for social learning: A relational understanding of adaptive capacity to climate change within organisations. Environment and Planning A, 40(4), 867-884. https://doi.org/10.1068/a39148

Penning-Rowsell E, Johnson C, Tunstall S (2006). "Signals" from pre-crisis discourse: Lessons from UK flooding for global environmental policy change? Global Environmental Change, 16, 323-339. https://doi.org/10.1016/j.gloenvcha.2006.01.006

Pielke RA, Doesken N, Bliss O, Green T, Chaffin C., Salas JD., ... Wolter, K (2005) Drought 2002 in Colorado: An unprecedented drought or a routine drought? Pure and Applied Geophysics, 162(8-9), 1455-1479. https://doi.org/10.1007/s00024-005-2679-6

Pulwarty RS, Melis TS (2001) Climate extremes and adaptive management on the Colorado River: Lessons from the 1997-1998 ENSO event. Journal of Environmental Management, 63(3), 307-324. https://doi.org/10.1006/jema.2001.0494

Ray AJ (2004). Linking Climate to Multi-Purpose Reservoir Management: Adaptive Capacity and Needs for Climate Information in the Gunnison Basin, Colorado. University of Colorado Boulder Dissertation.

Rayner S, Lach D, Ingram H (2005) Weather forecasts are for wimps: Why water resource managers do not use climate forecasts. Climatic Change, 69(2-3), 197-227.

https://doi.org/10.1007/s10584-005-3148-z

Slovic, P., \& Peters, E. (2006). Risk perception and affect. Current directions in psychological science, 15(6), 322-325.

Travis WR (2014) Weather and climate extremes: Pacemakers of adaptation? Weather and Climate Extremes, 5(1), 29-39. https://doi.org/10.1016/j.wace.2014.08.001 
Weick KE (1995) Sensemaking in Organizations. Thousand Oaks, CA: Sage Publications Yin RK (2014) Case Study Research: Design and Methods (5th ed.). Sage Publications 
Table 1. Summary of Selected Cases by Attribute

\begin{tabular}{|l|l|l|l|l|l|}
\hline Case No. & $\begin{array}{l}\text { Organization } \\
\text { type }\end{array}$ & $\begin{array}{l}\text { Business } \\
\text { type }\end{array}$ & Customer use & Storage & $\begin{array}{l}\text { Total water/people } \\
\text { served }\end{array}$ \\
\hline 1 & $\begin{array}{l}\text { Water } \\
\text { conservancy } \\
\text { district }\end{array}$ & Wholesale & $\begin{array}{l}\text { Irrigation } \\
\text { Augmentation }\end{array}$ & $\begin{array}{l}\text { Total reservoir } \\
\text { storage 44,000 AF }\end{array}$ & $\begin{array}{l}26,000 \mathrm{AF} \text { in annual } \\
\text { contracts }\end{array}$ \\
\hline $\begin{array}{l}\text { Water } \\
\text { conservancy } \\
\text { district }\end{array}$ & Retail & Domestic use & $\begin{array}{l}\text { Total reservoir } \\
\text { storage 11,960 AF }\end{array}$ & $\begin{array}{l}\text { 33,000 accounts } \\
80,000 \text { people } \\
10,000 \text { AF per year }\end{array}$ \\
\hline 3 & $\begin{array}{l}\text { Water } \\
\text { district }\end{array}$ & Wholesale & $\begin{array}{l}\text { Irrigation } \\
\text { Augmentation }\end{array}$ & $\begin{array}{l}\text { Total reservoir } \\
\text { storage 108,087 } \\
\text { AF }\end{array}$ & $\begin{array}{l}1857 \text { AF in } \\
\text { augmentation } \\
106,230 \text { AF available } \\
\text { for irrigation (amount } \\
\text { used varies year to } \\
\text { year) }\end{array}$ \\
\hline 4 & Municipality & Retail & $\begin{array}{l}\text { Domestic use } \\
\text { Irrigation }\end{array}$ & No storage & $\begin{array}{l}3500 \text { accounts } \\
2000 \text { AF per year }\end{array}$ \\
\hline 5 & Municipality & Retail & $\begin{array}{l}\text { Domestic use } \\
\text { Irrigation }\end{array}$ & No storage & $\begin{array}{l}10,000 \text { people } \\
3377 \text { AF per year }\end{array}$ \\
\hline
\end{tabular}

Figure 1: U.S. Drought Monitor Maps for mid-July during 2002 and 2012 droughts.

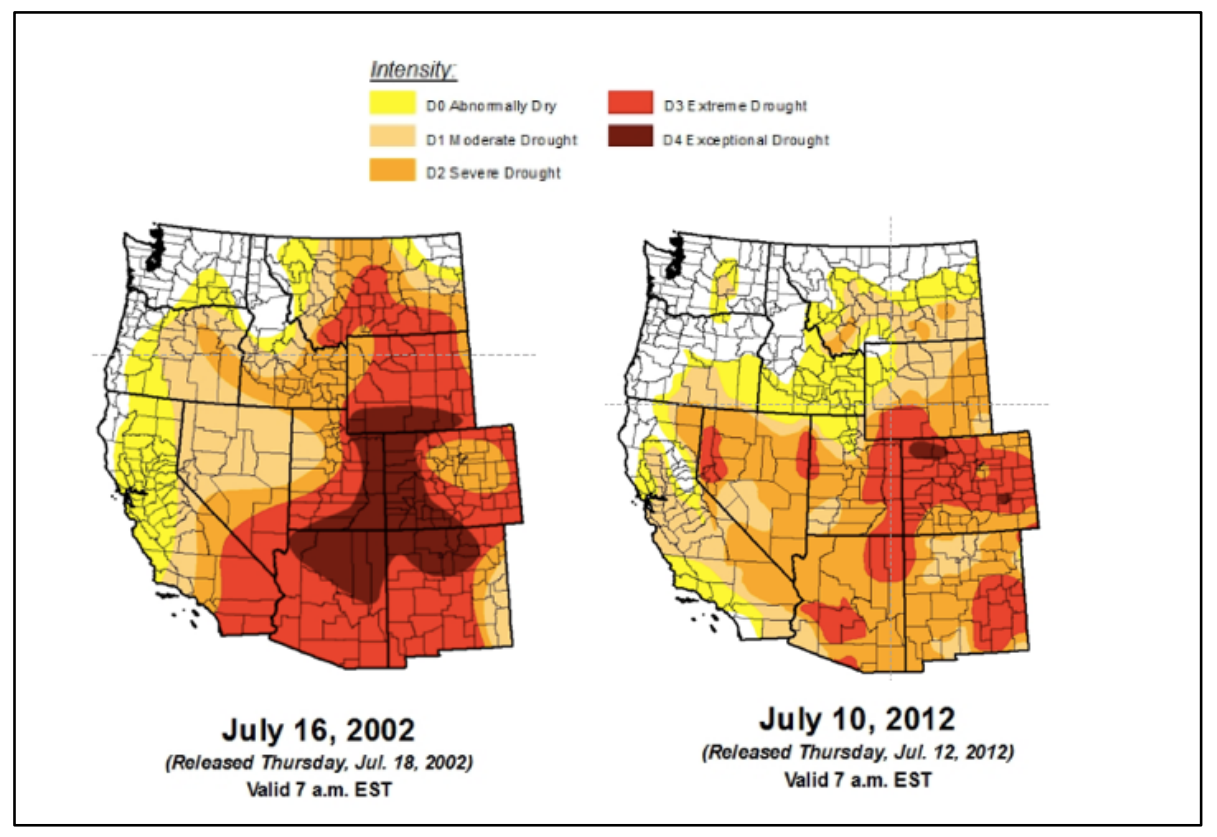

